\title{
Hydrochemical and Isotopic Characterisation of Groundwaters in the Eastern Region of Ghana
}

\author{
Samuel Y. Ganyaglo ${ }^{1}$, Bruce Banoeng-Yakubo ${ }^{2}$, Shiloh Osae ${ }^{1}$, Samuel B. Dampare ${ }^{1,3}$, \\ Joseph R. Fianko', Mohammad A. H. Bhuiyan ${ }^{3}$ \\ ${ }^{1}$ National Nuclear Research Institute, Ghana Atomic Energy Commission, Legon-Accra, Ghana \\ ${ }^{2}$ Department of Geology, University of Ghana, Legon-Accra, Ghana \\ ${ }^{3}$ Department of Earth Sciences, Okayama University, Okayama, Japan \\ E-mail: sganyaglo@yahoo.co.uk \\ Received December 27, 2009; revised January 20, 2010; accepted January 23, 2010
}

\begin{abstract}
Major ions and stable isotopes of groundwater in the Cape Coast granitoid complex (G1) and Lower Birimian (LB) formations in the Eastern Region of Ghana were evaluated to establish the source of recharge to the groundwater system. Five major hydrochemical facies were identified in the various rocks in the study area. They are calcium-magnesium-bicarbonate, sodium bicarbonate, sodium chloride and calcium chloride waters and mixed or non dominant water type. Sodium chloride and calcium chloride waters dominate aquifers of the Cape Coast granitoid complex whereas calcium-magnesium-bicarbonate is the dominant hydrochemical facies in the Lower Birimian aquifers. The most probable geochemical process responsible for the evolution of these hydrochemical facies is dissolution of minerals in the various rock types. Stable isotope composition of the groundwaters established that the recharge to the groundwater system is derived from rainfall.
\end{abstract}

Keywords: Hydrochemistry, Isotopes, Groundwater, Ghana

\section{Introduction}

Over the years groundwater has been one of the major sources of water supply to the rural communities in the Eastern Region of Ghana. This is partially due to drying out of most streams during the dry season and to a lesser extent, pollution of the streams and rivers, which require high cost of treatment before supply. The exploitation of this vital resource dates as far back as the pre-colonial era through the construction of hand-dug wells. These wells were dug through the overburden and weathered rock material. The hand-dug wells did not yield sufficient water during the dry season and their shallow nature rendered them vulnerable to contamination from runoff and anthropogenic activities. As a result, a more effective and hygienic system of water supply in the form of boreholes as the cheapest and most reliable means of meeting the water supply needs of the people was initiated [1,2]. The region has therefore witnessed numerous borehole-drilling programmes including the 3000-borehole programme, which covered five other regions in southern Ghana.
A large amount of hydrogeological and hydrochemical data have been generated through drilling activities in this region. However, as a result of unreliability of the data generated and the lack of a database, not much has been done in understanding the hydrochemical properties of the aquifers as a means of establishing the recharge regimes for the better management of the aquifer systems. The hydrochemical nature of the groundwaters has also not been thoroughly established. It is therefore difficult to predict the chemistry of groundwater and recharge areas.

The chemical composition of groundwater is controlled by many factors including composition of precipitation, mineralogy of the watershed and aquifer materials, aquifer characteristics, climate and topography [3]. These factors combine to create diverse water types that change spatially and temporally. These spatial changes in the water types can be evaluated and used to trace the recharge source(s) to the groundwater system.

The main focus of this study is to establish the recharge regime through groundwater sampling, looking at major ions and stable isotopes of the groundwaters. Specific objectives include identification of hydrochemical 
facies of the groundwaters and geochemical processes responsible for the various hydrochemical facies. It is intended to provide a database for sharing with stakeholders in the water sector, and to monitor and check land use practices in the recharge areas to ensure the safety of groundwater usage in the area.

\section{Study Area}

\subsection{Location}

The study area lies within latitudes $5^{\circ} 45^{\prime} \mathrm{N}$ to $6^{\circ} 30^{\prime} \mathrm{N}$ and longitudes $0^{\circ} 00^{\prime}$ to $1^{\circ} 00^{\prime} \mathrm{W}$. It covers an area of about $7414 \mathrm{~km}^{2}$. It is bounded on the north by Brong Ahafo region, south by Central region, west by Ashanti region, and east by Volta region and southeast by Greater Accra region. It consists of Akwapim North and South, New Juabeng, Suhum Kraboa Coaltar, Kwabibirem and East Akim districts (Figure 1).

\subsection{Climate}

The study area lies within the wet semi-equatorial climatic zone, characterized by two rainfall maxima, followed by a prolonged dry season. The first rainy season is from May to June with the heaviest rainfall in June, and the second rainy season is from September to October. On the basis of recent meteorological data (1993 to 2003) obtained from the Ghana Meteorological Agency (GMA), annual mean rainfall varies from $1206 \mathrm{~mm}$ at Nsawam to $1487 \mathrm{~mm}$ at Kibi. Figure 2 is a bar chart showing the total annual rainfall pattern in Koforidua area. The main vegetative zone is the moist semi-deciduous forest.

\subsection{Geology and Hydrogeology}

The study area is made up of the Cape Coast granitoid complex (G1) and the Lower Birimian (LB) rocks (Figure 3). The Cape Coast granitoid complex comprises a heterogeneous group of rocks occupying most of Suhum Kraboa Coal Tar, New Juabeng, the northwestern corner of the Akwapim North and part of the Akwapim South districts. The bulk of the Cape Coast granitoid complex is a granitic to quartz dioritic gneiss, which in the field is seen to change gradationally from fine to medium grained,

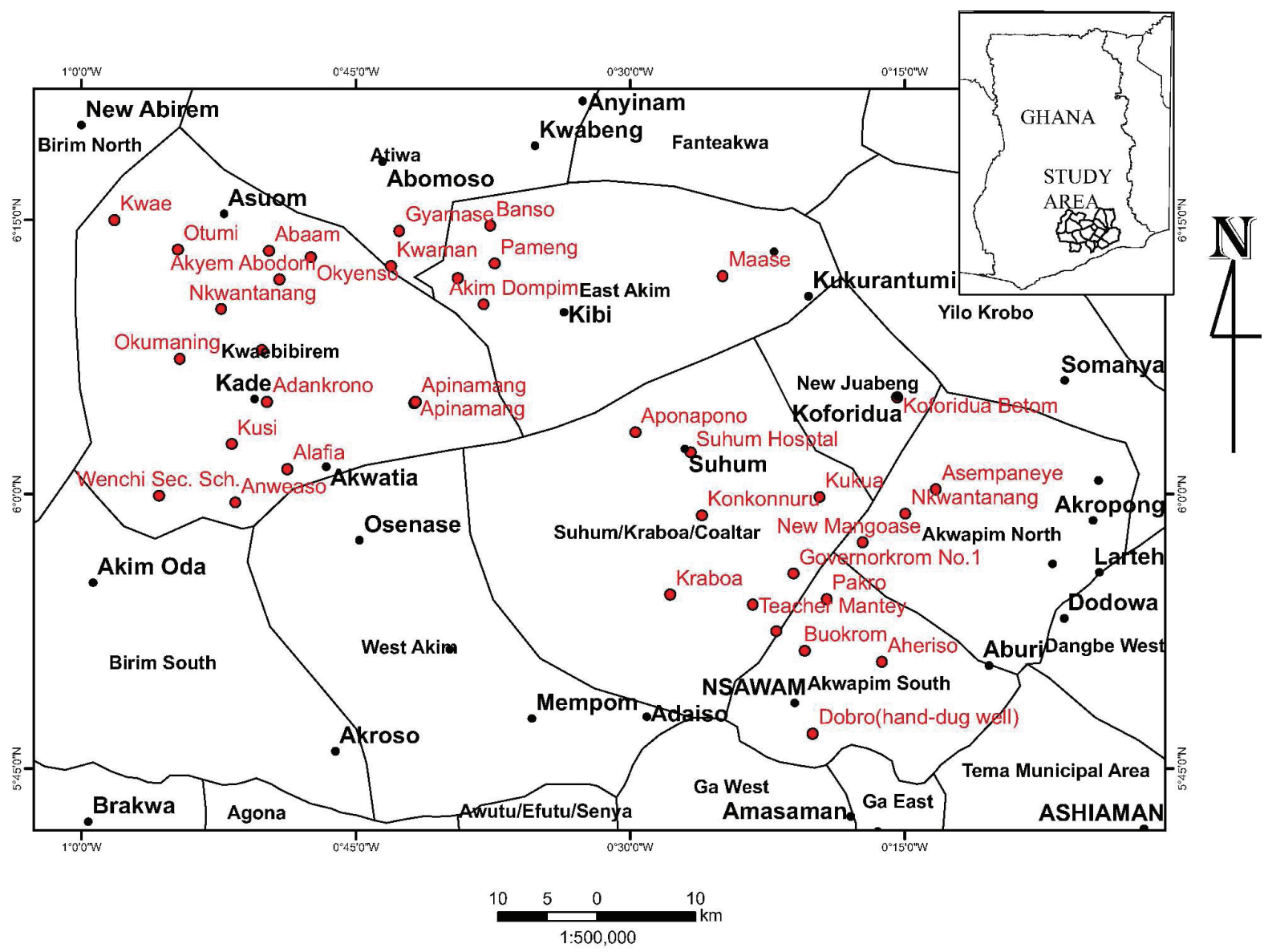

Figure 1. Location map of the study area. 


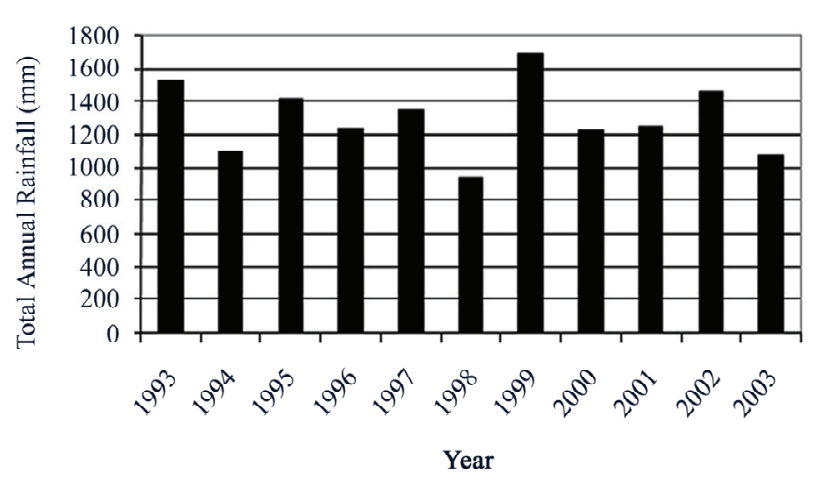

Figure 2. Total annual rainfall at Koforidua from 1993 to 2003.

foliated biotite quartz diorite gneiss to exclusively hornblende-quartz-diorite gneiss [4]. The rock types present in the Lower Birimian are greywackes with turbidite features [5], phyllites, slates, schists, weakly metamorphosed tuffs and lavas. Some of the phyllites contain pyrite and carbonaceous matter. The mode of groundwater occurrence in the study area is through the develop- ment of secondary porosities or permeabilities as a result of fracturing, jointing, shearing and deep weathering [2,6,7]. The fractures developed from tectonic movement, pressure relief due to erosion of overburden rock, shrinking during cooling of the rock mass and the compression and tensional forces caused by regional tectonic stresses [7, 8]). Most of the groundwaters in the study area occur in the weathered zone [1]. Available records indicate that borehole yield varies from $12 \mathrm{l} / \mathrm{min}$ to $150 \mathrm{l} / \mathrm{min}$ in the Cape Coast granitoid complex and $8 \mathrm{l} / \mathrm{min}$ to $360 \mathrm{1} / \mathrm{min}$ in the Lower Birimian. Average yield in the Cape Coast granitoid is $51 \mathrm{l} / \mathrm{min}$ whereas average yield in the Lower Birimian is $108 \mathrm{l} / \mathrm{min}$. Borehole lithologic logs could not be obtained for all the boreholes sampled. Hence depth, yield and static water levels (SWL) were not recorded for some of the boreholes as shown in the data presented in Appendix 1. Estimated depth of drilling, yield, and SWL were based on boreholes for which lithologic logs were obtained. Average depth of drilling is about $33 \mathrm{~m}$ for aquifers in the Cape Coast granitoid and $43 \mathrm{~m}$ for aquifers in the Lower Birimian. The general static water level in the area ranged from $1.63 \mathrm{~m}$ to $10.30 \mathrm{~m}$ in the Lower

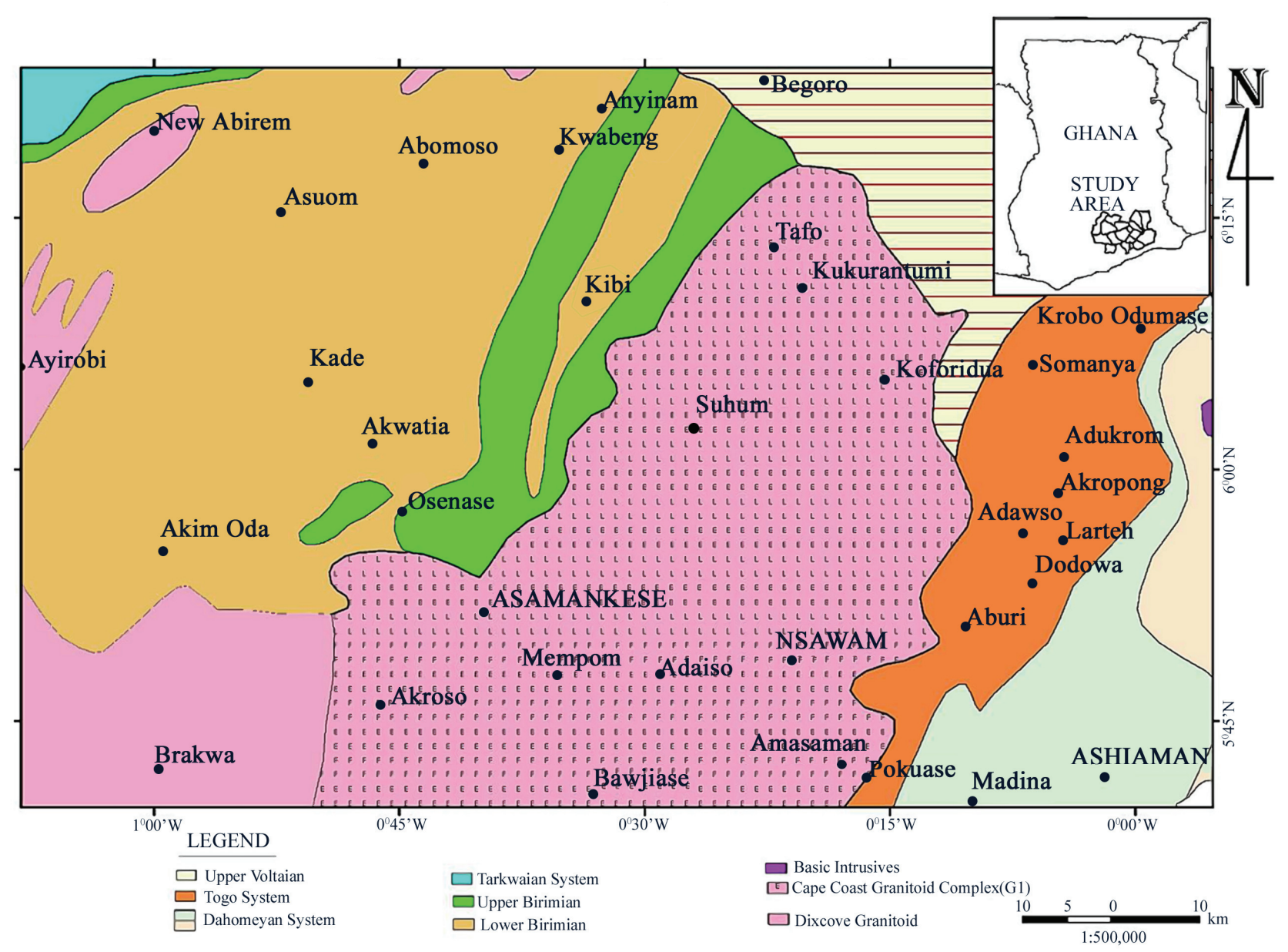

Figure 3. Geological map of the study area. 
Birimian aquifers. The mean static water level is $6.15 \pm 3.0 \mathrm{~m}$. The static water levels in the Cape Coast granitoid ranged from 0 to $5.14 \mathrm{~m}$ with the mean value of $2.35 \pm 1.54 \mathrm{~m}$.

\section{Methodology}

A total of 38 boreholes were sampled. The sampling points are shown in Figure 1. Eighteen (18) samples were taken from rocks of the Cape Coast granitoid complex whereas 20 samples were from Lower Birimian rocks.

All water samples were collected in $50 \mathrm{ml}$ pre-conditioned high-density polyethylene bottles. They were conditioned by washing initially with detergent, then with $10 \%$ percent nitric acid, and finally rinsing several times with distilled water. This was carried out to ensure that the sample bottles were free from contaminants.

At the sampling point, the boreholes ware pumped for about 5 minutes to purge the aquifer of stagnant water to acquire fresh aquifer samples for analysis. 5 minutes pumping was allowed, because in most of the communities visited, pumping was already in progress. The $\mathrm{pH}$ and temperature were stabilised within the five minutes of pumping. Samples were initially collected in a sterilised bucket immediately after purging the aquifer and quickly transferred into sampling bottles. Samples were taken in duplicate for major ion and stable isotope analyses. Prior to this, field parameters were measured. Basic parameters measured in the field were temperature, $\mathrm{pH}$, and electrical conductivity. Samples earmarked for major ion analyses were filtered on site through 0.45 micron meter cellulose filters with the aid of hand operated vacuum pump.

The samples were preserved in a refrigerator until they were transported to the laboratory for chemical analysis. The major ions were analyzed at the Ecological laboratory, University of Ghana, Legon with Dionex-120 ion chromatograph. The accuracy of the analyses was estimated from the charge balance error (CBE) [9], which is within $\pm 5 \%$ for all samples.

The analysis of oxygen isotope ratio of 14 samples from the study area was determined using a VG Sira 10 mass spectrometer with automatic inlet at the Geological Institute, University of Copenhagen. The measurements of deuterium in the water samples were carried out using Euro Vector elemental analyzer (EA; EuroPyrOH-3100) at the Institute of Physics and Astronomy, University of Aarhus, Denmark. The results for both isotopes were expressed in per mil (\%) deviation from the Vienna Standard Mean Ocean Water (VSMOW) using the delta $(\delta)$ - scale. Reproducibility was better than $0.1 \%$ for $\delta^{18} \mathrm{O}$ and about $1 \%$ for $\delta^{2} \mathrm{H}$.

The Piper 1944 Trilinear diagram was employed to define the various chemical evolution of groundwater in the area. The diagram displays the relative concentrations of the major cations and anions on two separate plots, together with a central diamond plot where the points from the two trilinear plots are projected. The central diamond-shaped field (quadrilateral field) is used to show the overall chemical character of the water. Subdivisions of the diamond field represent water type categories that form the basis for one common classification scheme for natural waters [9]. The diagram was plotted using Groundwater Chart (GW-Chart) software.

\section{Results and Discussion}

\subsection{Hydrochemistry}

A statistical summary of chemical parameters measured in the 38 groundwater samples is presented in Tables 1 and 2. The $\mathrm{pH}$ of groundwater varies from 4.2 to 7.2 in the Cape Coast granitoid complex aquifers with a mean of 6.1 and standard deviation of 0.8 (Table 1). Majority of the samples in these aquifers falls within natural $\mathrm{pH}$ range of 4.5-7.0. In the Lower Birimian aquifers the $\mathrm{pH}$ varies from 3.0 to 6.3 with a mean of 4.1 and standard deviation of 1.0 (Table 2). The $\mathrm{pH}$ is generally low in the Lower Birimian aquifers. Field temperatures vary from 25.3 in the Lower Birimian aquifers to $31.9{ }^{\circ} \mathrm{C}$ in the Cape Coast granitoid aquifers. The lower temperatures occur at higher topographic elevations and the higher temperatures occur at lower topographic elevations. The higher topographic elevations are characterised by moist semi-deciduous forest with high amount of rainfall as mentioned in Subsection 2.2. This may have contributed to the lower temperatures at higher elevations. Figure 4

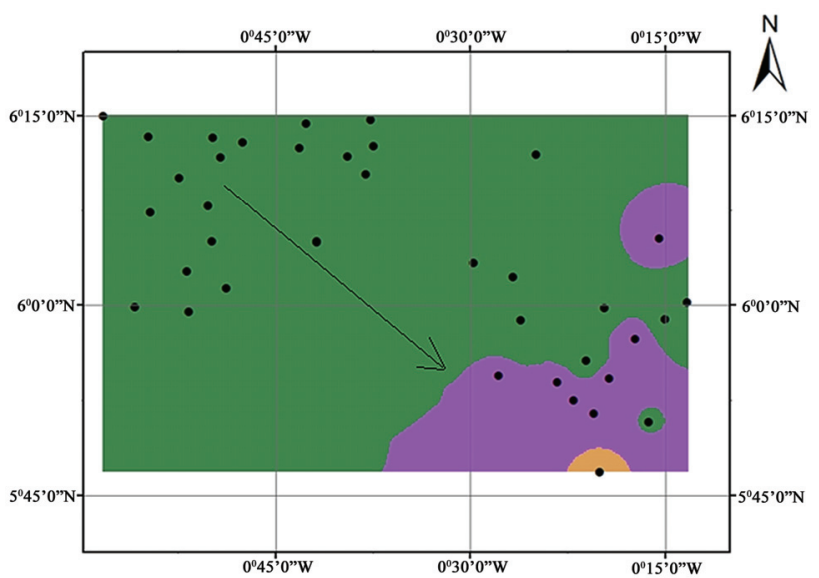

Legend

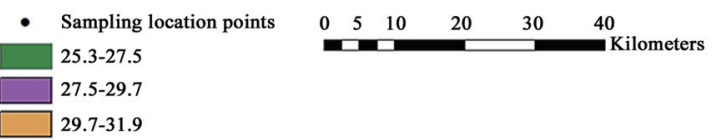

Figure 4. Spatial distribution of temperature in the study area. 
shows the temperature distribution pattern in the area. The arrow points to the region of higher temperature where aquifers of the Cape Coast granitoid occur. In this region the climatic condition changes slightly to the savanna grassland with drier conditions. This may have led to the higher temperatures in the lower topographic elevation. Temperature influences dissolved mineral constituents in groundwater.

At higher temperatures groundwater dissolve more minerals resulting in elevated TDS and consequently conductivity. The higher topographic elevations which correspond to lower temperatures also correspond to lower TDS and conductivities thus describing a recharge area. The lower topographic areas of higher temperatures also correspond to higher TDS and conductivities describing a discharge area. The flow path is thus indicated in Figure 4. Temperature and $\mathrm{pH}$ influence dissolution and precipitation of minerals in groundwater. In general water with low $\mathrm{pH}(<6.5)$ could be acidic and corrosive. Acidic waters could leach metal ions such as: iron, manganese, copper, lead, and zinc from the aquifer. The $\mathrm{pH}$ of the groundwater in the lower Birimian rocks are generally lower than 6.5. It ranges from 3.0 to 6.3 , showing strongly acidic to slightly acidic conditions. The acidic nature of the waters could trigger various chemical reactions in the groundwater.

Conductivity values from 55 to $1999 \mu \mathrm{S} / \mathrm{cm}$ were also recorded while TDS ranged from 31.9 to $968.3 \mathrm{mg} / \mathrm{l}$.
Detail hydrochemical data is presented in Appendices 1a and $1 \mathrm{~b}$.

The groundwater samples from the two main geological formations were plotted on the Piper 1944 Trillinear diagram to identify the chemical facies in the various aquifers in these geological terrains. The Cape Coast granitoid complex revealed five major water types (Figure 5). These are calcium magnesium bicarbonate $\left(\mathrm{CaMgHCO}_{3}\right)$, sodium bicarbonate $\left(\mathrm{NaHCO}_{3}\right)$, mixed water type (water type in which none of the ions is dominant), calcium chloride $\left(\mathrm{CaCl}_{2}\right)$ and sodium chloride $(\mathrm{NaCl})$. From the plots of hydrochemistry (Figure 5), $\mathrm{CaCl}_{2}$ and $\mathrm{NaCl}$ are the dominant water types in this geological terrain. The source of these water types is usually attributed to seawater intrusion for aquifers located along the coast [10]. However, the area under investigation is located in the forest zone where total annual rainfall varies from $1206 \mathrm{~mm}$ to $1487 \mathrm{~mm}$. The granitoids weather to form thick layers composed of clay. Cation exchange reactions are therefore suspected from clay minerals and might be responsible for these $\mathrm{NaCl}$ and $\mathrm{CaCl}_{2}$ water types. The source of $\mathrm{Cl}^{-}$in the groundwater could also be from infiltrating rainwater and carried to the groundwater zone. It is also possible that halite from previous aerosols may have concentrated $\mathrm{NaCl}$ in the soil zone. This is possible in the tropical zone with rainfall events followed by prolonged dry seasons during which period; it is possible to precipitate halite in the soil.

Table 1. Statistical summary of hydrochemical data in the Cape Coast granitoid complex.

\begin{tabular}{ccccc}
\hline Parameter & Minimum & Maximum & Mean & Standard Deviation \\
\hline $\mathrm{pH}$ & 4.2 & 7.2 & 6.1 & 0.8 \\
Temp & 25.3 & 31.9 & 27.4 & 1.5 \\
Conductivity & 365 & 1999 & 791.1 & 445.9 \\
$\mathrm{Na}+$ & 14.2 & 251.6 & 66.3 & 52.8 \\
$\mathrm{~K}+$ & 1.4 & 49.0 & 5.8 & 10.9 \\
$\mathrm{Mg} 2+$ & 5.4 & 38.7 & 15.9 & 9.0 \\
$\mathrm{Ca}+$ & 12.6 & 234.2 & 43.5 & 50.6 \\
$\mathrm{Cl}-$ & 9.3 & 144.6 & 72.9 & 41.1 \\
SO42- & 6.9 & 508.3 & 61.3 & 115.3 \\
$\mathrm{HCO} 3-$ & 34.2 & 523.4 & 162.9 & 120.0 \\
TDS & 97.2 & 968.3 & 61.3 & 201.4 \\
\hline
\end{tabular}

pH in pH-units, Temperature in ${ }^{\circ} \mathrm{C}$, Conductivity in $\mu \mathrm{S} / \mathrm{cm}, \mathrm{Na}^{+}$to TDS in $\mathrm{mg} / \mathrm{l}$

Table 2. Statistical summary of hydrochemical data in the Lower Birimian aquifers.

\begin{tabular}{ccccc}
\hline Parameter & Minimum & Maximum & Mean & Standard Deviation \\
\hline $\mathrm{pH}$ & 3.0 & 6.3 & 4.1 & 1.0 \\
Temperature & 25.4 & 27.2 & 26.4 & 0.5 \\
Conductivity & 55.0 & 439.0 & 209.2 & 124.3 \\
$\mathrm{Na}^{+}$ & 3.2 & 19.4 & 10.3 & 5.0 \\
$\mathrm{~K}^{+}$ & 0.1 & 4.5 & 1.1 & 0.9 \\
$\mathrm{Mg}^{2+}$ & 0.6 & 11.5 & 4.5 & 3.3 \\
$\mathrm{Ca}^{2+}$ & 28.8 & 10 & 7.4 \\
$\mathrm{Cl}^{-}$ & 2.2 & 28.5 & 9.5 & 8.6 \\
$\mathrm{SO}_{4}{ }^{-}$ & 0.1 & 184.2 & 3.1 & 6.2 \\
$\mathrm{HCO}_{3}^{-}$ & 32.9 & 180.2 & 76.3 & 4.7 \\
$\mathrm{TDS}$ & 31.9 & & 81.8 & 42.9 \\
\hline
\end{tabular}

pH in pH-units, Temperature in ${ }^{\circ} \mathrm{C}$, Conductivity in $\mu \mathrm{S} / \mathrm{cm}, \mathrm{Na}^{+}$to TDS in $\mathrm{mg} / \mathrm{l}$ 
The other possible source of $\mathrm{Cl}^{-}$may be from fluid inclusions in the granitic gneiss rock, which are characteristic of minerals of basement rocks [11]. Figure 6 shows that $\mathrm{CaMgHCO}_{3}$, mixed water types, $\mathrm{NaCl}$ and $\mathrm{CaCl}_{2}$ waters occur in the granitic gneiss. The mineralogical composition of this rock type is $60 \%$ plagioclase, $10 \%$ microcline, $25 \%$ quartz and $5 \%$ biotite [4].

The higher concentration of $\mathrm{Ca}^{2+}$ and $\mathrm{Na}^{+}$in the groundwaters may therefore be due to the dissolution of plagioclase feldspars. $\mathrm{HCO}_{3}{ }^{-}$may have been generated in the soil zone en route to the groundwater zone as a result of decomposition of organic matter, which releases carbon dioxide that reacts with water in the soil zone. The reaction generates weak carbonic acid $\left(\mathrm{H}_{2} \mathrm{CO}_{3}\right)$ that aids the breakdown of minerals in the rocks resulting in the release of the cations responsible for the various hydrochemical facies. Mixed water types also occur in the granodioritic gneiss and granite. Biotite granite contains $\mathrm{NaCl}$ water.

Two major water types are identified from the aquifers of the Lower Birimian. They include calcium-magnesium -bicarbonate and mixed water types. Phyllite, argillite, tuff and schist aquifers contain calcium-magnesiumbicarbonate water type (Figure 7). The occurrence of this water type in these aquifers may be due to the mineralogical composition of the rocks. The common minerals in these rocks are the calcic-plagioclase feldspars, hornblende, biotite, pyroxenes and olivine. The breakdown of the calcic-plagioclase feldspars and pyroxenes may be responsible for calcium in this water type, whereas hornblende, pyroxenes and olivine may be responsible for the magnesium in the water.

Very few samples from phyllite aquifers exhibit mixed water types.

\subsection{Stable Isotopes}

Analyses of stable isotopes were carried out on the sampled groundwater. The $\delta^{18} \mathrm{O}$ values range from $-2.2 \%$ to $-3.4 \%$. The mean is $-2.7 \%$ with a standard deviation of $0.4 \%$. The $\delta^{2} \mathrm{H}$ ranges from $-6 \%$ to $-17 \%$. The mean is $-11 \%$ with a standard deviation of $3 \%$. The negative values of Oxygen-18 and deuterium are indicative of depletion of oxygen-18 and deuterium relative to the Vienna Standard Mean Ocean Water (VSMOW). The isotopic data is presented in Appendix 2. A plot of $\delta^{2} \mathrm{H}$ $\%$ VSMOW against $\delta^{18} \mathrm{O} \% \mathrm{VSMOW}$ of the analysed samples is shown in Figure 8. Results of the oxygen-18 and deuterium analyses are found to cluster around the Global Meteoric Water Line (GMWL) given by the equation $\delta^{2} \mathrm{H}=8 \delta^{18} \mathrm{O}+10$ [12]. The groundwater in the study area is therefore derived from rainfall. Figures 9 and 10 show the spatial distributions of oxygen-18 and deuterium in the study area with sampling points.

\section{Conclusions}

The hydrochemical facies in the groundwaters in the Eastern Region of Ghana are $\mathrm{Ca}-\mathrm{Mg}-\mathrm{HCO}_{3}, \mathrm{NaHCO}_{3}$, $\mathrm{NaCl}, \mathrm{CaCl}_{2}$ and mixed water types. With respect to the underlying geological formations in the area, the major water types in the Cape Coast granitoid complex are $\mathrm{Ca}-\mathrm{Mg}-\mathrm{HCO}_{3}, \mathrm{NaHCO}_{3}, \mathrm{NaCl}$ and $\mathrm{CaCl}_{2}$ and mixed water types. The most predominant water types in the

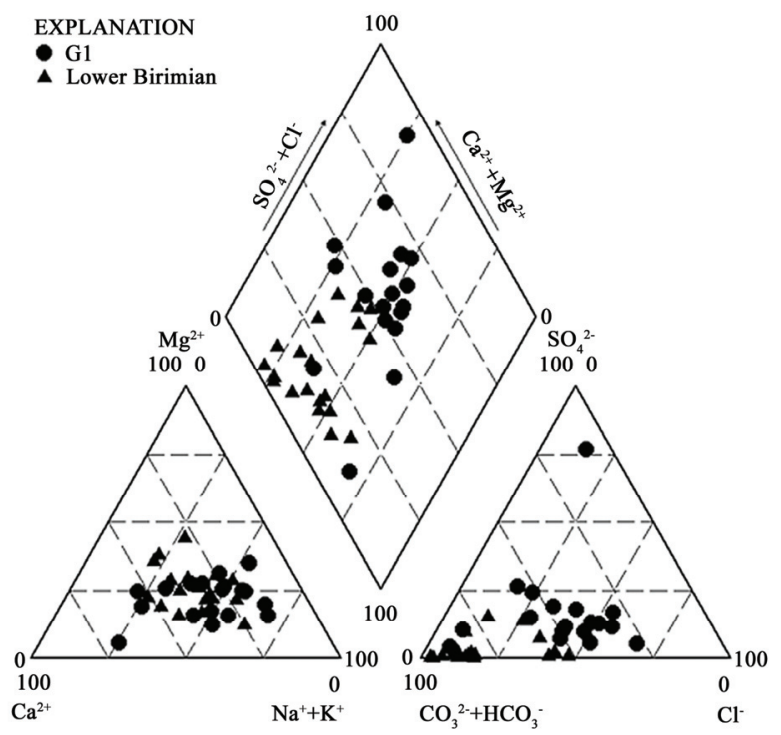

Figure 5. Trilinear piper diagram showing the chemical character of groundwater in the Cape Coast granitoid (G1) and Lower Birimian.

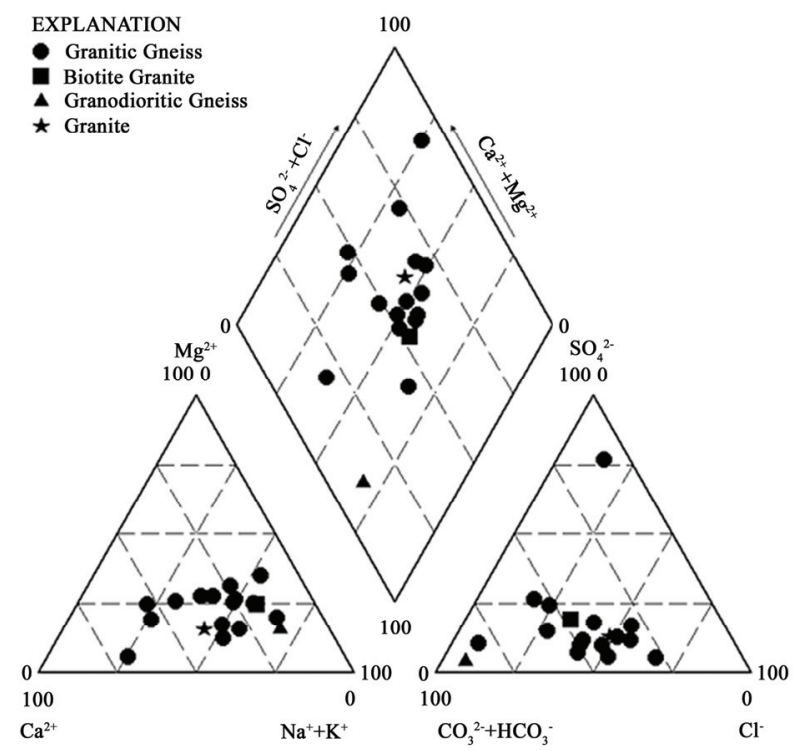

Figure 6. Trilinear piper diagram showing the hydrochemical facies in the various rock types in the Cape Coast granitoid complex. 


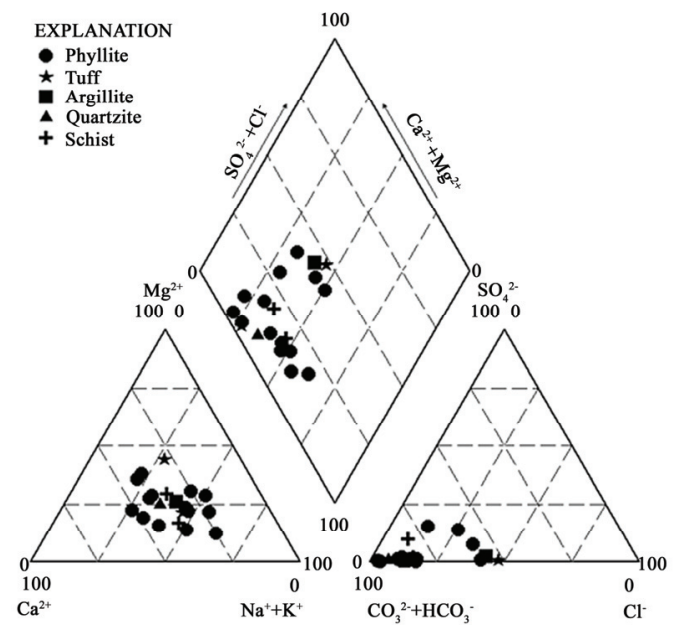

Figure 7. Trilinear piper diagram showing the hydrochemical facies in some of the rock types in the Lower Birimian.

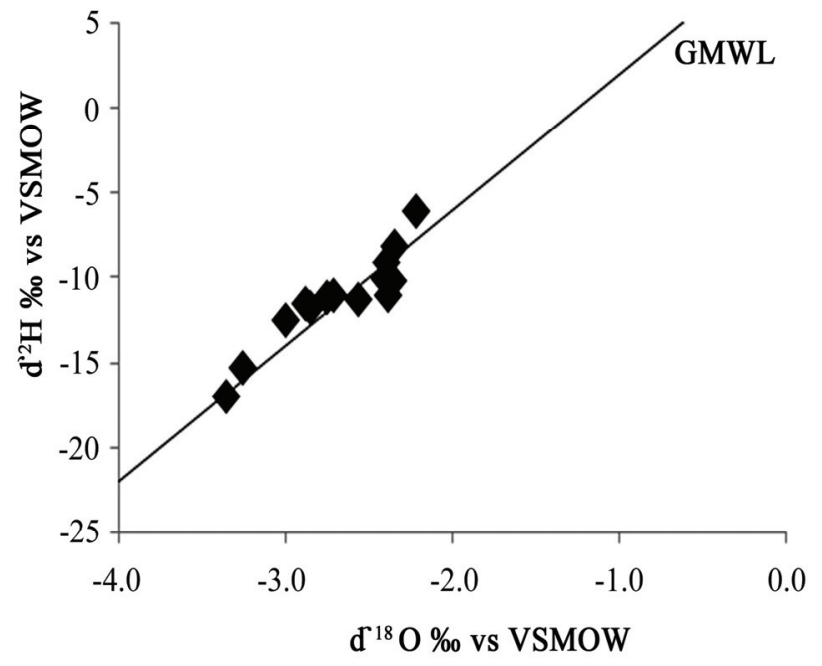

Figure 8. Stable isotopes of Eastern Region groundwaters.

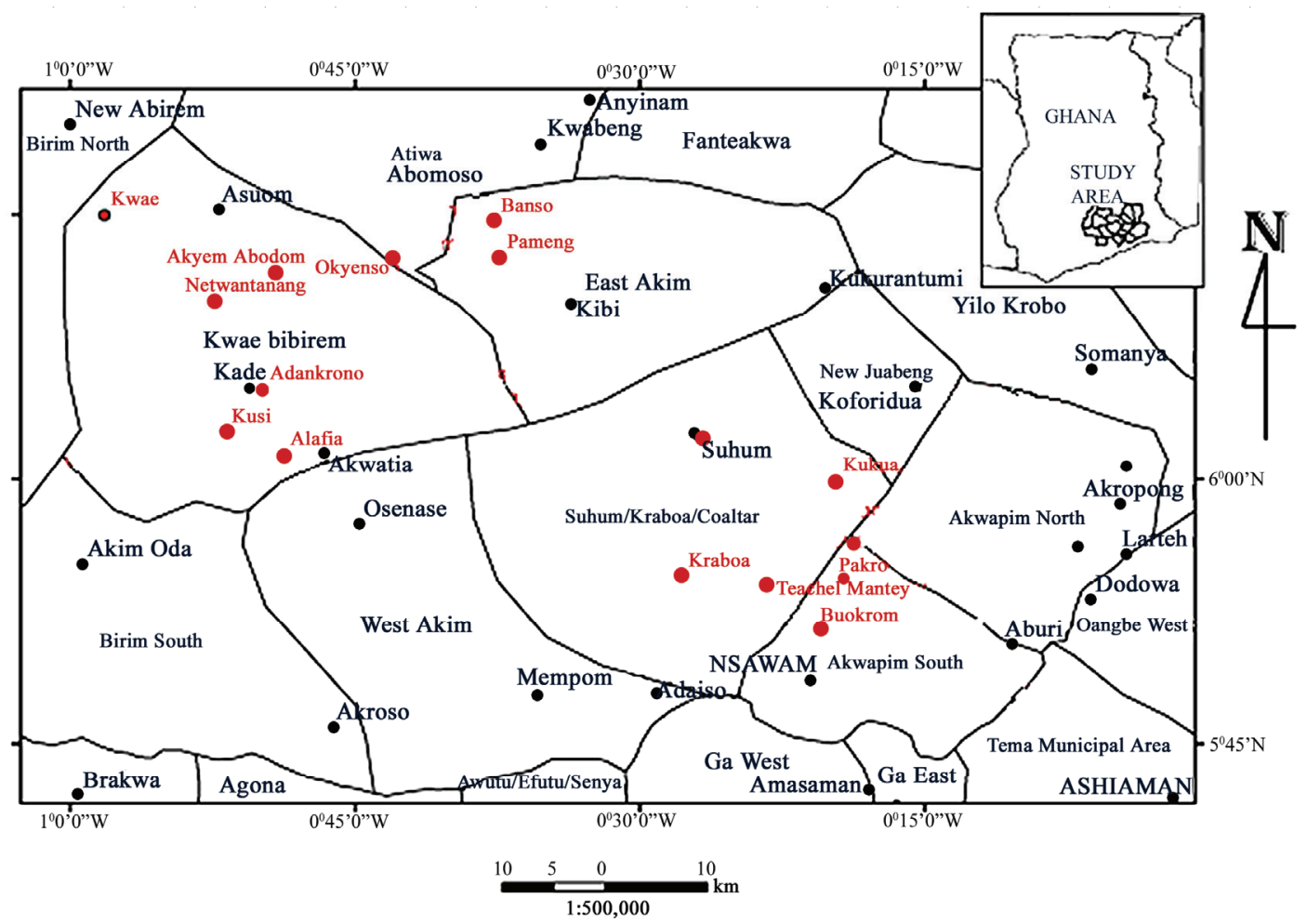

Figure 9. Sampling points for stable isotopes in the study area (highlighted in red).

Cape Coats granitoid are $\mathrm{NaCl}$ and $\mathrm{CaCl}_{2}$ waters. The major facies in the Lower Birimian aquifers are $\mathrm{Ca}$ $\mathrm{Mg}-\mathrm{HCO}_{3}$, and mixed water types. The geochemical processes that might be governing the presence of the various ions in solution include dissolution of minerals in the rock. A plot of $\delta^{2} \mathrm{H} \%$ VSMOW against $\delta^{18} \mathrm{O}$ $\%$ VSMOW established the groundwater recharge to be from rainfall.

\section{Acknowledgements}

The authors gratefully acknowledge Danida-Enreca Hydrogeological Project for financial and logistical support. We thank technicians of the Ecological Laboratory of the University of Ghana, Legon, for their assistance during the chemical analysis of water samples. 


\section{References}

[1] G. O. Kesse, "The mineral and rock resources of Ghana," Rotterdam, 1985.

[2] J. A. Akudago, K. Kankam-Yeboah, L. P. Chegbeleh, and M. Nashigaki, "Assesment of well design and sustainability in hard rock formations in northern Ghana," Hydrogeology Journal, Vol. 15, pp. 789-798, December 2006.

[3] C. Guler, G. D. Thyne, J. E. McCray, and A. K. Turner, "Evaluation of graphical and multivariate statistical methods for classification of water chemistry data," Hydrogeology Journal, Vol. 10, pp. 455-473, May 2002.

[4] S. M. Ahmed, P. K. Blay, S. B. Castor, and G. J. Coakley, "Geology of $(1 / 4)^{\circ}$ field sheets Nos. 33 Winneba NE 59, 61, and 62 Accra SW, NW and NE," Ghana Geological Survey Bulletin, No. 32, 1997.

[5] S. S. Trashliev, "The Geology of $1 / 4$ field sheets 82 (Wiawso SE) and 46 (Asankragwa NE)," Unpublished Report of Ghana Geological Survey, 1974.

[6] B. Banoeng-Yakubo, "Occurrence of groundwater in basement complex rocks of the Upper Regions of Ghana," M.Sc. dissertation, Obefemi-Awolowo University, Geology Department, Nigeria, 1989.

[7] B. K. Banoeng-Yakubo, "The application of remote sensing and geographical information systems to hydrogeological studies in the upper west region, Ghana," Unpublished Ph.D. Thesis, University of Ghana, Legon, June 2000.

[8] S. N. Davis and L. J. Turk, "Optimum depth of wells in crystalline rocks, Groundwater,” Vol. 2, No. 2, pp. 6-11, 1964.

[9] R. A. Freeze and J. A. Cherry, "Groundwater," Prentice Hall, Englewood Cliffs, NJ, USA, 1979.

[10] B. K. Kortatsi, "Hydrochemical characterization of groundwater in the Accra plains of Ghana," Environmental Geology, Vol. 50, pp. 299-311, April 2006

[11] G. Faure, "Principles and applications of inorganic geochemistry," Prentice Hall, 1991.

[12] H. Craig, "Isotopic variations in meteoric waters," Science, Vol. 133, No. 3465, pp. 1702-1703, May 1961. 
Appendix 1a. Hydrochemical data in the Cape Coast granitoid complex aquifers.

\begin{tabular}{|c|c|c|c|c|c|c|c|c|c|c|}
\hline Community & Station & $\begin{array}{c}\text { Field } \\
\text { Borehole I.D. }\end{array}$ & $\begin{array}{l}\text { Date of } \\
\text { sampling }\end{array}$ & $\begin{array}{l}\text { Depth } \\
(\mathrm{m})\end{array}$ & $\begin{array}{c}\text { Yield } \\
(1 / \mathrm{min})\end{array}$ & $\begin{array}{c}\text { S.W.L } \\
(\mathrm{m})\end{array}$ & $\mathrm{pH}$ & $\begin{array}{l}\text { Temp } \\
\left({ }^{\circ} \mathrm{C}\right)\end{array}$ & $\begin{array}{c}\text { Cond } \\
(\mu \mathrm{s} / \mathrm{cm})\end{array}$ & $\begin{array}{l}\text { TDS } \\
(\mathrm{mg} / \mathrm{l})\end{array}$ \\
\hline Boukrom & 1 & $\mathrm{BU}$ & $24-01-03$ & 34 & 15 & 5.10 & 6.6 & 28.4 & 755 & 376.0 \\
\hline Aheriso & 2 & $\mathrm{AH}$ & $24-01-03$ & 40 & 12 & 1.40 & 6.4 & 27.3 & 765 & 396.4 \\
\hline New Mangoase & 4 & NM & $24-01-03$ & 22 & 150 & 2.38 & 6.3 & 28.6 & 1084 & 534.9 \\
\hline Nkwantanang & 5 & NK & $24-01-03$ & & & & 6.4 & 26.3 & 570 & 243.5 \\
\hline Kukua & 6 & $\mathrm{KU}$ & $24-01-03$ & 33 & 50 & & 7.2 & 26.7 & 1582 & 968.3 \\
\hline Governorkrom No.1 & 7 & GK & $24-01-03$ & & & & 7.0 & 26.6 & 1999 & 640.6 \\
\hline Dobro (hand-dug well) & 8 & DO & $21-02-03$ & 6 & 6 & 3.30 & 6.4 & 31.9 & 436 & 235.8 \\
\hline Teacher Mantey & 9 & $\mathrm{TM}$ & $21-02-03$ & & & & 6.3 & 27.8 & 955 & 465.6 \\
\hline Panpanso No.1 & 10 & $\mathrm{PP}$ & $21-02-03$ & & & & 6.5 & 28.0 & 549 & 297.2 \\
\hline Konkonnuru & 11 & KK & $21-02-03$ & 37 & 50 & 0 & 6.8 & 25.9 & 903 & 446 \\
\hline Kraboa & 12 & KB & $21-02-03$ & & & & 6.6 & 27.8 & 597 & 335.1 \\
\hline Suhum Hospital & 13 & $\mathrm{SU}$ & $22-02-03$ & & & & 5.5 & 27.0 & 406 & 233.6 \\
\hline Aponapono & 14 & AP & $22-02-03$ & & & & 6 & 25.3 & 365 & 97.15 \\
\hline Koforidua Betom & 15 & KB & $22-02-03$ & & & & 5.8 & 28.4 & 443 & 223.9 \\
\hline Kwae & 17 & KW & $25-02-03$ & 37 & 50 & 3.82 & 4.4 & 26.1 & 484 & 259.8 \\
\hline Maase & 18 & MA & $26-02-03$ & 28 & 40 & 2.20 & 4.2 & 26.7 & 502 & 267.8 \\
\hline
\end{tabular}

Appendix 1a continued.

\begin{tabular}{|c|c|c|c|c|c|c|c|c|c|c|}
\hline Community & Station & $\begin{array}{c}\text { Field Borehole } \\
\text { I.D. }\end{array}$ & $\begin{array}{c}\mathrm{Na}^{+} \\
(\mathrm{mg} / \mathrm{l})\end{array}$ & $\begin{array}{c}\mathrm{K}^{+} \\
(\mathrm{mg} / \mathrm{l})\end{array}$ & $\begin{array}{l}\mathrm{Mg}^{2+} \\
(\mathrm{mg} / \mathrm{l})\end{array}$ & $\begin{array}{l}\mathrm{Ca}^{2+} \\
(\mathrm{mg} / \mathrm{l})\end{array}$ & $\begin{array}{c}\mathrm{Cl}^{-} \\
(\mathrm{mg} / \mathrm{l})\end{array}$ & $\begin{array}{l}\mathrm{SO}_{4}^{2-} \\
(\mathrm{mg} / \mathrm{l})\end{array}$ & $\begin{array}{r}\mathrm{HCO}_{3}^{-} \\
(\mathrm{mg} / 1)\end{array}$ & $\mathrm{CBE}$ \\
\hline Boukrom & 1 & $\mathrm{BU}$ & 83.5 & 2.8 & 29.5 & 16.9 & 110.7 & 55.0 & 142.5 & 3 \\
\hline Aheriso & 2 & $\mathrm{AH}$ & 79.9 & 4.3 & 22.2 & 36.9 & 104.2 & 39.5 & 207.4 & 1 \\
\hline Pakro & 3 & PA & 66.6 & 1.4 & 15.3 & 19.0 & 63.5 & 1.94 & 213.1 & -2 \\
\hline New Mangoase & 4 & NM & 103 & 6.5 & 38.7 & 48.9 & 172.5 & 85.9 & 196.8 & 2 \\
\hline Nkwantanang & 5 & NK & 70.5 & 1.5 & 16.8 & 21.1 & 69.6 & 52.2 & 118.4 & 5 \\
\hline Kukua & 6 & $\mathrm{KU}$ & 99.3 & 2.6 & 11.8 & 234 & 98.6 & 540.3 & 110.2 & 4 \\
\hline Governorkrom No.1 & 7 & GK & 252 & 2.0 & 30.3 & 50.1 & 85.97 & 98.2 & 625 & 4 \\
\hline Dobro (hand-dug well) & 8 & DO & 35.8 & 7.4 & 15.2 & 31.7 & 13.5 & 22.1 & 203.3 & 5 \\
\hline Teacher Mantey & 9 & TM & 57.4 & 3.4 & 16.7 & 25.3 & 120.9 & 29.0 & 97.2 & -3 \\
\hline Panpanso No.1 & 10 & PP & 64.3 & 1.6 & 10.2 & 12.6 & 47.1 & 31.3 & 168.4 & -5 \\
\hline Konkonnuru & 11 & KK & 46.0 & 3.6 & 18.1 & 86.1 & 52.2 & 102.6 & 272.1 & -1 \\
\hline Kraboa & 12 & $\mathrm{~KB}$ & 42.5 & 49 & 8.9 & 41.7 & 76.2 & 36.5 & 154.3 & 4 \\
\hline Suhum Hospital & 13 & SU & 45.2 & 2.7 & 6.9 & 20.8 & 54.6 & 18.7 & 84.2 & 5 \\
\hline Aponapono & 14 & AP & 14.2 & 2.4 & 9.0 & 32.3 & 31.9 & 43.0 & 73 & 1 \\
\hline Koforidua Betom & 15 & $\mathrm{~KB}$ & 31.3 & 2.8 & 11.5 & 21.3 & 57.3 & 4.8 & 123.2 & -4 \\
\hline Asempaneye & 16 & AS & 54.8 & 4.4 & 10.4 & 33.4 & 104.9 & 15.2 & 146.4 & -6 \\
\hline Kwae & 17 & KW & 28.0 & 2.4 & 5.4 & 22.7 & 56.2 & 18.02 & 75.2 & -5 \\
\hline Maase & 18 & MA & 19.9 & 4.3 & 9.8 & 27.7 & 67.8 & 11.4 & 50.9 & -3 \\
\hline
\end{tabular}

Appendix 1b. Hydrochemical data in the Lower Birimian.

\begin{tabular}{|c|c|c|c|c|c|c|c|c|c|c|}
\hline Community & Station & $\begin{array}{c}\text { Field } \\
\text { Borehole I.D. }\end{array}$ & $\begin{array}{l}\text { Date of } \\
\text { Sampling }\end{array}$ & $\begin{array}{l}\text { Depth } \\
\text { (m) }\end{array}$ & $\begin{array}{l}\text { Yield } \\
\left(\mathrm{m}^{3}\right)\end{array}$ & $\begin{array}{l}\text { S.W.L. } \\
(1 / \mathrm{min})\end{array}$ & $\mathrm{pH}$ & $\begin{array}{l}\text { Temp } \\
\left({ }^{\circ} \mathrm{C}\right)\end{array}$ & $\begin{array}{l}\text { Cond } \\
(\mu \mathrm{s} / \mathrm{m})\end{array}$ & $\begin{array}{l}\text { TDS } \\
(\mathrm{mg} / \mathrm{l})\end{array}$ \\
\hline Apinamang & 19 & AP1 & $24-05-03$ & 46 & 50 & 3.45 & 4 & 26.8 & 167 & 68.36 \\
\hline Apinamang & 20 & AP2 & $24-05-03$ & 45 & 100 & 5.53 & 3 & 26.6 & 294 & 146 \\
\hline Alafia & 21 & $\mathrm{AL}$ & $24-05-03$ & 46 & 36 & 7.25 & 3 & 26.7 & 439 & 135.8 \\
\hline Anweaso & 22 & AN & $24-05-03$ & 39 & 120 & 2.55 & 6 & 27.2 & 364 & 70.68 \\
\hline Wenchi Sec. Sch. & 23 & WE & $24-05-03$ & & & & 4 & 26.7 & 214 & 117.8 \\
\hline Kusi & 24 & $\mathrm{KU}$ & $24-05-03$ & & & & 4 & 27 & 127 & 40.53 \\
\hline Okumaning & 25 & $\mathrm{OK}$ & $24-05-03$ & 41 & 150 & 9.1 & 6 & 26.2 & 116 & 53.38 \\
\hline Subi & 26 & SB & $24-05-03$ & & & & 4 & 25.7 & 55 & 31.94 \\
\hline Nkwantanang & 27 & NK & $24-05-03$ & 43 & 200 & 1.86 & 4 & 26.2 & 91 & 49.62 \\
\hline Otumi & 28 & OT & $24-05-03$ & 55 & 60 & 1.5 & 5 & 25.4 & 273 & 98.37 \\
\hline Adankrono & 29 & AD & $25-05-03$ & 31 & 60 & 2.49 & 4 & 27.1 & 170 & 82.67 \\
\hline Akyem Abodom & 30 & AA & $25-05-03$ & 52 & 120 & 2.76 & 3 & 26.4 & 120 & 67.29 \\
\hline Abaam & 31 & $\mathrm{AB}$ & $25-05-03$ & & & & 4 & 25.6 & 239 & 99.99 \\
\hline Okyenso & 32 & OS & $25-05-03$ & 51 & 360 & 12.46 & 5 & 25.9 & 335 & 127.9 \\
\hline Kwaman & 33 & KW & $25-05-03$ & 43 & 8 & 10.3 & 3 & 26.6 & 58 & 35.37 \\
\hline Akim Akropong & 34 & AK & $25-05-03$ & 31 & 20 & 1.63 & 6 & 26.2 & 330 & 180.2 \\
\hline Gyamase & 35 & GY & $25-05-03$ & & & & 3 & 26.8 & 435 & 34.54 \\
\hline Pameng & 36 & PA & $25-05-03$ & 48 & 200 & 8 & 3 & 26.5 & 63 & 44.68 \\
\hline Banso & 37 & $\mathrm{BA}$ & $25-05-03$ & 32 & 60 & 2.26 & 4 & 26.6 & 205 & 105.2 \\
\hline Akim Dompim & 38 & $\mathrm{AM}$ & $25-05-03$ & 43 & 40 & 7.78 & 3 & 25.8 & 89 & 44.8 \\
\hline
\end{tabular}


Appendix 1b continued.

\begin{tabular}{|c|c|c|c|c|c|c|c|c|c|c|}
\hline Community & Station & $\begin{array}{c}\text { Field } \\
\text { Borehole I.D. }\end{array}$ & $\begin{array}{c}\mathrm{Na}^{+} \\
(\mathrm{mg} / \mathrm{l})\end{array}$ & $\begin{array}{c}\mathrm{K}^{+} \\
(\mathrm{mg} / \mathrm{l})\end{array}$ & $\begin{array}{l}\mathrm{Mg}^{2+} \\
(\mathrm{mg} / \mathrm{l})\end{array}$ & $\begin{array}{c}\mathrm{Ca}^{2+} \\
(\mathrm{mg} / \mathrm{l})\end{array}$ & $\begin{array}{c}\mathrm{Cl}^{-} \\
(\mathrm{mg} / \mathrm{l})\end{array}$ & $\begin{array}{l}\mathrm{SO}_{4}{ }^{2-} \\
(\mathrm{mg} / \mathrm{l})\end{array}$ & $\begin{array}{l}\mathrm{HCO}_{3}^{-} \\
(\mathrm{mg} / \mathrm{l})\end{array}$ & $\mathrm{CBE}$ \\
\hline Apinamang & 19 & AP1 & 15.1 & 1.26 & 4.7 & 5.6 & 15.4 & 4.41 & 43.92 & 4 \\
\hline Apinamang & 20 & AP2 & 17.2 & 1.61 & 8.7 & 21.8 & 13.3 & 19.4 & 113.5 & -1 \\
\hline Alafia & 21 & $\mathrm{AL}$ & 14.6 & 0.85 & 7.4 & 17.2 & 3.2 & 10.2 & 124 & -5 \\
\hline Anweaso & 22 & $\mathrm{AN}$ & 9.18 & 1.63 & 9.1 & 15.7 & 11.8 & 11.2 & 74.5 & 5 \\
\hline Wenchi Sec. Sch. & 23 & WE & 19 & 0.93 & 7.1 & 9.7 & 27.2 & 0.75 & 67.1 & 1 \\
\hline Kusi & 24 & $\mathrm{KU}$ & 6.89 & 0.82 & 1.5 & 2.64 & 0.4 & 4.5 & 31.5 & -4 \\
\hline Okumaning & 25 & $\mathrm{OK}$ & 7.63 & 0.93 & 2 & 5.11 & 12.2 & 3.7 & 24.3 & -3 \\
\hline Subi & 26 & SUB & 5.58 & 0.95 & 0.6 & 2.13 & 1.3 & 3.3 & 19.9 & -1 \\
\hline Nkwantanang & 27 & NK & 8.22 & 0.76 & 2.3 & 5.06 & 3.6 & 1.4 & 44.5 & -2 \\
\hline Otumi & 28 & OT & 9.8 & 0.83 & 4.5 & 17.2 & 1 & 5.4 & 101.6 & -4 \\
\hline Adankrono & 29 & $\mathrm{AD}$ & 7.93 & 0.8 & 2.8 & 5.85 & 13.2 & 3.4 & 33.4 & -5 \\
\hline Akyem Abodom & 30 & AA & 8.1 & 0.73 & 3.1 & 8.26 & 0.7 & 5.4 & 59.5 & -3 \\
\hline Abaam & 31 & $\mathrm{AB}$ & 13 & 0.99 & 11 & 12.3 & 2.17 & 0.19 & 117.1 & 4 \\
\hline Okyenso & 32 & OS & 7.94 & 1.29 & 7.6 & 14.9 & 10.8 & 18.8 & 74.9 & -5 \\
\hline Kwaman & 33 & KW & 4.99 & 0.65 & 0.8 & 3.22 & 1.6 & 2.1 & 24.5 & -3 \\
\hline Akim Akropong & 34 & AK & 19.4 & 4.52 & 6.8 & 28.8 & 28.5 & 20.6 & 113.5 & -2 \\
\hline Gyamase & 35 & GY & 3.15 & 0.76 & 0.7 & 3.49 & 0.5 & 4.7 & 18.2 & -2 \\
\hline Pameng & 36 & PA & 5.12 & 0.09 & 1 & 3.51 & 2 & 1.5 & 26.4 & -4 \\
\hline Banso & 37 & $\mathrm{BA}$ & 15.7 & 1.07 & 7 & 13.7 & 7.09 & 9.5 & 101.3 & -2 \\
\hline Akim Dompim & 38 & $\mathrm{AM}$ & 6.72 & 1 & 1.8 & 4.05 & 0.6 & 2.6 & 40.9 & -5 \\
\hline
\end{tabular}

Appendix 2. Stable isotopes data.

\begin{tabular}{cccc}
\hline Community & Sample I.D. & $\delta^{18} \mathrm{O}$ & $\delta^{2} \mathrm{H}$ \\
\hline Pakro & PA & -2.8 & -11.0 \\
Boukrom & BU & -2.4 & -11.0 \\
Kukua & KU & -2.6 & -11.0 \\
Alafia & AL & -2.9 & -12.0 \\
Teacher Mantey & TM & -2.4 & 10.0 \\
Kraboa & KB & -2.9 & -12.0 \\
Kusi & KS & -2.4 & -10.0 \\
Kwae & KW & -2.4 & -8.0 \\
Nkwantanang & NK & -2.7 & -11.0 \\
Akyem Abodom & AA & -2.4 & -9.0 \\
Adankrono & AD & -3.3 & 15.0 \\
Banso & BA & -2.2 & -6.0 \\
Okyenso & OS & -3.4 & -17.0 \\
Pameng & PA & -3.0 & -13.0 \\
\hline
\end{tabular}

